\title{
Using Isotope Technology for Surface Water Environment Research in Southern Hanoi
}

\author{
Vo Thi Anh1, Tran Khanh Minh1, Trinh Van Giap1, Ha Lan Anh1, Nguyen Thanh Cong2, \\ Nguyen Hong Thinh'1, Vu Hoai ${ }^{1}$ \\ ${ }^{1}$ Institute for Nuclear Science and Technology, Hanoi, Vietnam \\ ${ }^{2}$ Vinh University, Vinh, Vietnam \\ Email: vothianhanh@yahoo.com
}

Received 20 June 2016; accepted 19 July 2016; published 22 July 2016

Copyright (C) 2016 by authors and Scientific Research Publishing Inc.

This work is licensed under the Creative Commons Attribution International License (CC BY). http://creativecommons.org/licenses/by/4.0/

(c) (i) Open Access

\begin{abstract}
The surface water in the southern of Hanoi capital is researched by identifying $\delta^{2} \mathrm{H}$ and $\delta^{18} \mathrm{O}$ stable

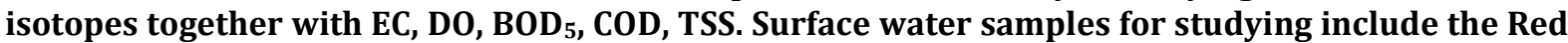
river, Nhue river and Kim Nguu river, Thanh Nhan lake, Yen So lake and Van Quan lake were collected in the dry season (April) and the rainy season (August) in 2015. The stable isotope analysis results showed that the $\delta^{18} \mathrm{O}$ values is a range from $-42.53 \%$ to $-64.05 \%$ and, the $\delta^{2} \mathrm{H}$ values is the range from $\mathbf{- 5 . 0 9 \%}$ to $\mathbf{- 8 . 7 9 \%}$ under global meteoric waterline (in the water vapor region). The $\delta^{2} \mathrm{H}$ results of the rivers and lakes in the dry season are more negative than the rainy season with a small difference. The $\delta^{18} 0$ results of lakes in the dry season are more negative than the rainy season, but the $\delta^{18} 0$ results of river in the dry season are more positive than the rainy season. The results of the EC, BOD, COD, DO, TSS analysis showed that surface water environment has changed clearly in the two seasons and the contamination level in the dry season is usually higher than the rainy season. The lakes and rivers strongly influenced by human activities led to seriously pollution are Van Quan lake and Yen So lake, Nhue river and Kim Nguu river.
\end{abstract}

\section{Keywords}

Isotope Technology, Surface Water Quality, Change in Difference Seasons

\section{Introduction}

Hanoi Capital is the center of culture, economy and politics of the country. Thus, there is a very high population density in Hanoi, and demand for clean water and waste process is extremely large. The surface water qualities in rivers, streams, ponds and lakes in Hanoi are easily affected and transformed by human activities such as the 
activities of people, urbanization, industrialization and agriculture. The surface water from urban areas usually flocks the ToLich and the Kim Nguu rivers, and then exits Nhue River at Thanh Liet dam forced or pumped out through the Red River Yenso pump station [1]. Many studies indicate that the impact of human activities has caused change in the surface water qualities in urban areas, where high concentrated population, emission activities take place to strengthen magnitude [2].

Stable isotope technique was used early in the research mixture process of surface waters in the 1970s by differential independent author groups. The group of Kraus \& Mackey (1971) and the group of Mausui (1976) used $\delta^{18} \mathrm{O}$ stable isotopes for assessment to mixable progress of rivers [3]. The Behrens and Stichler group (1971) used $\delta^{2} \mathrm{H}$ stable isotopes for evaluation the mixture of Ranh and Main rivers [3]. Currently the stable isotope techniques combined with chemical analysis of the surface water samples were exploited and used effectively to assess surface water qualities such as the Katz et al. (1997) authors [4] and Liu Xiangchao et al. (2002) authors $[5]$.

Therefore, to apply the stable isotope techniques combined with traditional bio-chemical methods will help us to study the surface water qualities with modernly and highly effective approach in the south of Hanoi Capital.

\section{Site Description}

The lakes and rivers selected for the surface water research in the South of Hanoi are Thanh Nhan, Yen So and Van Quan lakes and Red, Nhue, Kim Nguu rivers. The samples collected in twice a year are the dry season (March, April) and wet season (August, September) in 2015 for evaluation surface water quality in two different seasons (Figure 1).

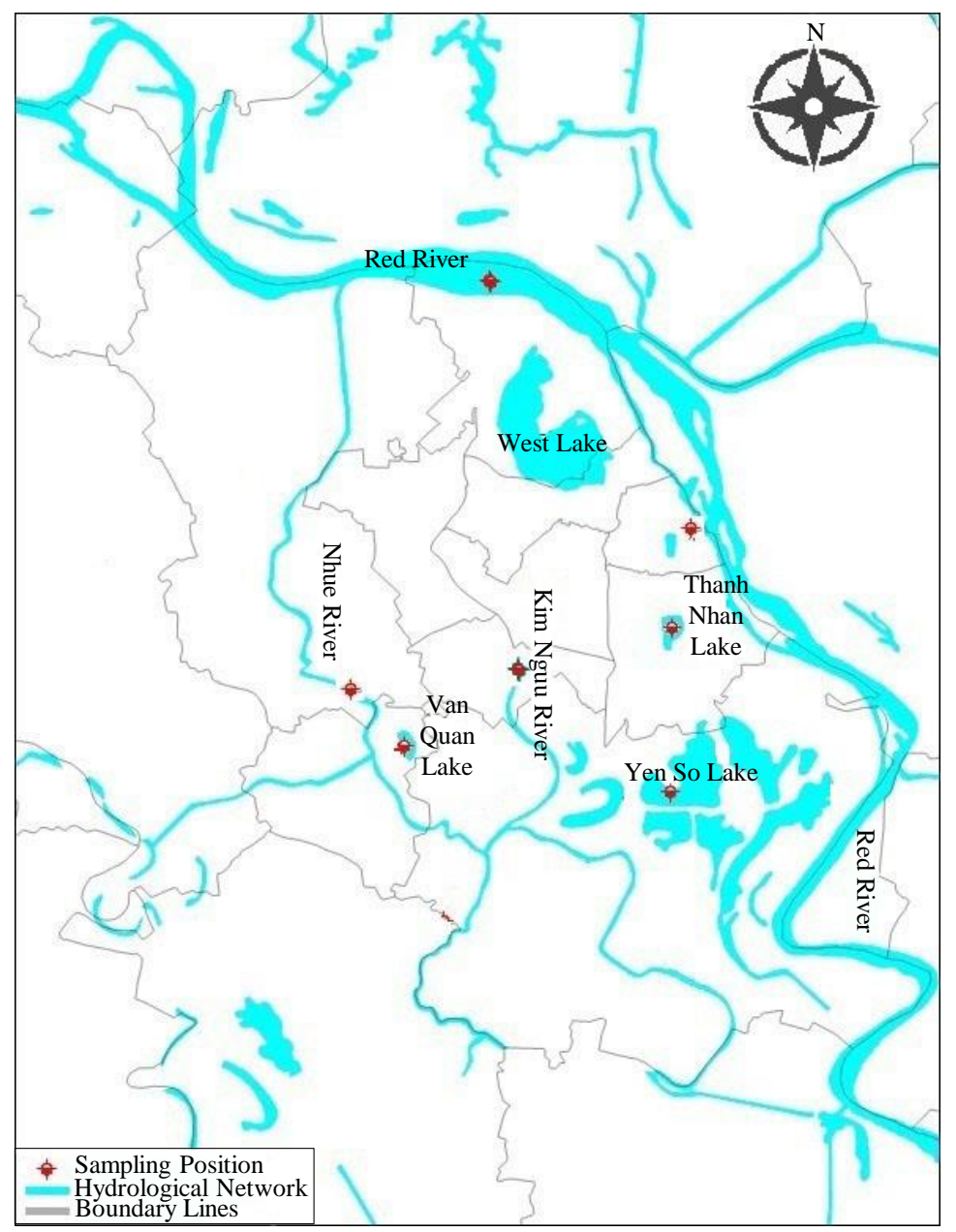

Figure 1. Sampling location map of the south of Hanoi. 


\section{Methods}

\subsection{Sampling Procedures and Preservation}

Sampling procedures and preservation for the $\delta^{18} \mathrm{O}$ and $\delta^{2} \mathrm{H}$ stable isotope analysis: Fill a $50 \mathrm{~mL}$, double capped, glass or polyethylene bottle directly from the source or from a secondary container. Clearly label the sample with all details. Make sure the bottles are tightly capped. During sampling, storage and transportation to the laboratory take care to avoid evaporation of the sample.

Sampling for bio-chemical analysis: sampling and preservation with TCVN 6663-6 (ISO 5667-6: 2005).

\subsection{Analytical Methods}

The determination of the $\delta^{18} \mathrm{O}$ and $\delta^{2} \mathrm{H}$ stable isotope in surface water samples is carried out on a LWIA-24D Laser mass spectrometer (Liquid Water Isotopes Analyzer) located at Isotopes Hydrology laboratory, Institute for Nuclear Science and Technology, 179 Hoang Quoc Viet Street, Vietnam.

Procedures of the $\delta^{18} \mathrm{O}$ and $\delta^{2} \mathrm{H}$ stable isotopes analysis in water samples comply with the IAEA standard operating procedure for the liquid water isotopes analyzer published in 2009 with a uncertainty $<0.1 \%$ for $\delta^{18} \mathrm{O}$ and $<0.3 \%$ for $\delta^{2} \mathrm{H}$.

Electrical conductivity, $\mathrm{pH}$ and dissolved oxygen are measured in the field with Seven Multil and Hana HI 9146 hand-held. Total Suspended Solids, biochemical oxygen demand, chemical oxygen demand are carried out at Isotopes Hydrology laboratory with Vietnam standards.

\section{Results and Discussion}

\subsection{Results}

The analytical results from rivers and lakes in the southern of Hanoi with the dry season and the rainy season are presented in Table 1 and Table 2 below.

Table 1. Results of the sample analysis from rivers and lakes in southern of Hanoi with the dry season in 2015.

\begin{tabular}{|c|c|c|c|c|c|c|c|c|c|c|}
\hline \multirow{2}{*}{ No } & \multirow{2}{*}{$\begin{array}{c}\text { Sample } \\
\text { ID }\end{array}$} & \multirow{2}{*}{ Location } & \multirow{2}{*}{$\delta^{2} \mathrm{H} \%$} & \multirow{2}{*}{$\begin{array}{c}\delta_{\%}^{18} \mathrm{O} \\
\%\end{array}$} & \multirow{2}{*}{$\begin{array}{c}\text { TSS } \\
\text { mg/L }\end{array}$} & \multirow{2}{*}{$\begin{array}{l}\text { EC } \\
\text { S/cm }\end{array}$} & \multirow{2}{*}{ pH } & DO & BOD $_{5}$ & COD \\
\hline & & & & & & & & \multicolumn{3}{|c|}{$\mathrm{mg} / \mathrm{L}$} \\
\hline 1 & HTN & Thanh Nhan lake & -42.53 & -5.09 & 15 & 138 & 8.79 & 5.02 & 3.2 & 5.5 \\
\hline 2 & HVQ & Van Quan lake & -49.33 & -6.27 & 36.7 & 355 & 7.91 & 3.39 & 176 & 249 \\
\hline 3 & HYS & Yen So lake & -50.02 & -8.79 & 26.8 & 345 & & 6.89 & 354 & 855 \\
\hline 4 & SHD & Red river & -64.05 & -7.05 & 21.8 & 189 & 8.03 & 7.52 & 5.2 & 10.1 \\
\hline 5 & SHG & Red river & -60.34 & -7.15 & 29.6 & 98.3 & 7.98 & 6.49 & 6.2 & 7.1 \\
\hline 6 & SKN & Kim Nguu river & -52.32 & -6.7 & 51 & 726 & 7.45 & 0 & 213 & 498 \\
\hline 7 & $\mathrm{SN}$ & Nhue river & -56.86 & -7.12 & 46 & 398 & & 0 & 226 & 364 \\
\hline
\end{tabular}

Table 2. Results of the sample analysis from rivers and lakes in southern of Hanoi with the rainy season in 2015.

\begin{tabular}{|c|c|c|c|c|c|c|c|c|c|c|}
\hline \multirow{2}{*}{ No } & \multirow{2}{*}{$\begin{array}{c}\text { Sample } \\
\text { ID }\end{array}$} & \multirow{2}{*}{ Location } & \multirow{2}{*}{$\delta^{2} \mathrm{H} \%$} & \multirow{2}{*}{$\begin{array}{c}\delta^{18} O \\
\%\end{array}$} & \multirow{2}{*}{$\begin{array}{c}\text { TSS } \\
\mathrm{mg} / \mathrm{L}\end{array}$} & \multirow{2}{*}{$\begin{array}{l}\text { EC } \\
\text { S/cm }\end{array}$} & \multirow{2}{*}{$\mathbf{p H}$} & DO & BOD $_{5}$ & COD \\
\hline & & & & & & & & \multicolumn{3}{|c|}{ mg/L } \\
\hline 1 & HTN & Thanh Nhan lake & -45.38 & -5.17 & 3.8 & 887 & & 5.11 & 3.5 & 4.78 \\
\hline 2 & HVQ & Van Quan lake & -45.01 & -4.87 & 17.4 & 798 & 7.49 & 4.29 & 231 & 359 \\
\hline 3 & HYS & Yen So lake & -49.74 & -6.73 & 28.5 & 508 & 7.41 & 7.43 & 376 & 796 \\
\hline 4 & SHD & Red river & -61.51 & -8.28 & 16 & 245 & 8.37 & 7.59 & 5.32 & 7.18 \\
\hline 5 & SHG & Red river & -59.62 & -8.67 & 20.4 & 265 & 6.37 & 6.89 & 5.55 & 7.64 \\
\hline 6 & SKN & Kim Nguu river & -49.03 & -6.82 & 26 & 850 & & 0 & 241 & 484 \\
\hline 7 & $\mathrm{SN}$ & Nhue river & -54.95 & -8.01 & 39 & 461 & & 0 & 298 & 477 \\
\hline
\end{tabular}




\subsection{EC Results}

Electrical conductivity in water samples related to ions in the water. Measurement results showed that the EC values of rivers and lakes in southern of Hanoi are very high; the value of EC in the rainy season tends to increase in the dry season. In the dry season, the highest EC value is $726 \mu \mathrm{S} / \mathrm{cm}$ at the river Kim Nguu. And in the rainy season, EC value of Thanh Nhan lake, Van Quan lake and Kim Nguu river are 887, 798, 850 $\mu \mathrm{S} / \mathrm{cm}$ respectively. These rivers and lakes are places activities of people impacted surface water quality

\subsection{DO, BOD ${ }_{5}$, COD Results}

Concentration of oxygen dissolved in surface water in the Kim Nguu and Nhue rivers are zero in both seasons showed seriously pollution levels of the rivers. And another of the lakes and rivers are range from $3.39 \mathrm{mg} / \mathrm{L}$ to $7.52 \mathrm{mg} / \mathrm{L}$ during the dry season; from $4.29 \mathrm{mg} / \mathrm{L}$ to $7.59 \mathrm{mg} / \mathrm{L}$ with the rainy season.

The chemical oxygen demand (COD) and the biochemical oxygen demand $\left(\mathrm{BOD}_{5}\right)$ of the lakes in the rainy season almost are higher than the dry season. The results of Nhue, Kim Nguu rivers and Van Quan, Yen So lakes are very high that exceeded the Vietnam National Standard-QCVN 08:2008/BTNMT.

\subsection{TSS Results}

The Total Suspended Solids results in the samples in the rainy season are lower than the dry season. And they accord with the Vietnam National Standard-QCVN 08:2008/BTNMT.

\subsection{Stable Isotope Results}

The stable isotopes Values of the lakes in the dry season and the rainy season are the range from $-42.53 \%$ o to $-50.02 \%$ with $\delta^{18} \mathrm{O}$ ratio isotope and $-5.09 \%$ to $-8.79 \%$ with $\delta^{2} \mathrm{H}$ ratio isotope. The rivers in the dry season and the rainy season are the range from $-49.03 \%$ to $-64.05 \%$ with $\delta^{18} \mathrm{O}$ ratio isotope and $-6.70 \%$ o to $-8.67 \%$ with $\delta^{2} \mathrm{H}$ ratio isotope. Looking in Figure 2, we see that the isotope values are under the global meteoric waterline and in the water vapor region.

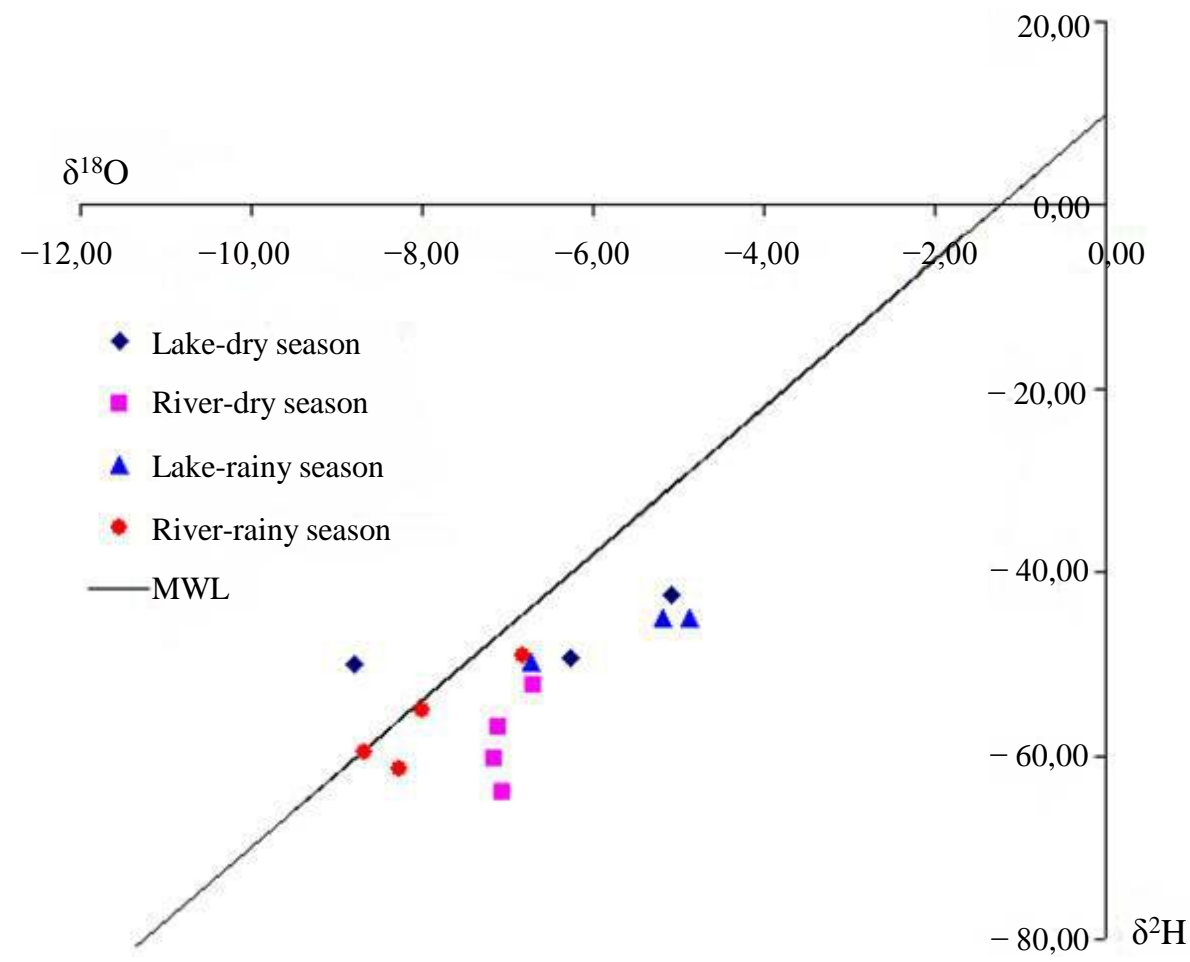

Figure 2. The $\delta^{2} \mathrm{H}$ and $\delta^{18} \mathrm{O}$ stable isotopes values of surface water samples in the South of Hanoi. 

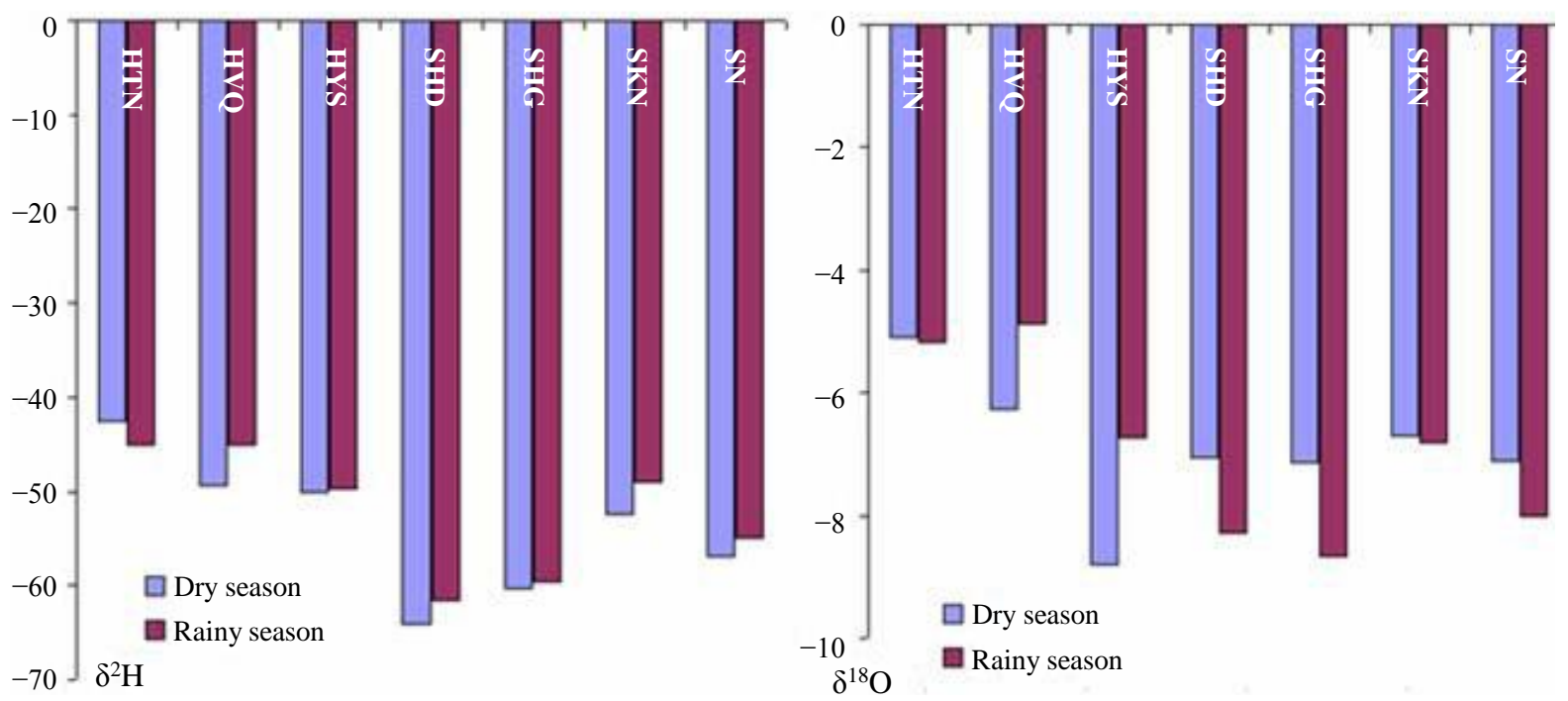

Figure 3. The $\delta^{2} \mathrm{H}$ and $\delta^{18} \mathrm{O}$ stable isotopes values of surface water samples in the dry season and rainy season.

The stable isotopes results also show that the $\delta^{2} \mathrm{H}$ values of rivers and lakes in the dry season are more negative than the rainy season with small difference. There are difference in the $\delta^{18} \mathrm{O}$ stable isotopes results between rivers and lakes in the dry season and the rainy season. The $\delta^{18} \mathrm{O}$ results of rivers in the rainy are more negative than in the dry season. But the $\delta^{18} \mathrm{O}$ results of lakes in the rainy are more positive than in the dry season (Figure 3 ).

Especially, the stable isotope values of the rivers are nearly the global meteoric waterline. It shows that there is contribution of rainwater into rivers in the South of Hanoi.

\subsection{Characteristics of Surface Water in the South of Hanoi}

When studies of stable isotope results, we see that there are $\delta^{18} \mathrm{O}$ different values between river samples and lake samples in the dry and the rainy seasons. The Thanh Nhan, Yen So and Van Quan lakes are artificial lakes which are influenced greatly from the human activities. The $\delta^{18} \mathrm{O}$ stable isotope values of lakes in the dry season are more negative than rainy season. Meanwhile, the Red, Nhue, Kim Nguu rivers have a natural origin. They are influenced from the human activities with the difference levels. The $\delta^{18} \mathrm{O}$ stable isotope values of rivers in the dry season are more positive than rainy season, against $\delta^{18} \mathrm{O}$ isotopes values in lakes.

The results of the EC, DO, BOD, COD, TSS analysis in surface water samples in the South of Hanoi Capital show that human activities has caused environmental pollution seriously such as Van Quan lake, Yen So lake, Nhue river and Kim Nguu river.

\section{Conclusion}

Using the $\delta^{18} \mathrm{O}$ and $\delta^{2} \mathrm{H}$ stable isotope techniques together with the EC, TSS and biochemistry to assess surface water quality in the South of Hanoi is a new scientific approach. The isotope results show that they are under the global meteoric waterline and in the water vapor region. The biochemical analysis results also showed that the level of pollution in rivers and lakes in the South of Hanoi have tended to increase over time [2] [5].

\section{Acknowledgements}

The authors thank the Institute for Nuclear Science and Technology for providing facilities and financial assistance to undertake the work from project of Ministry of Science and Technology. The authors thank Mr. Nguyen Thanh Binh working Hanoi Centre for Environmental Monitoring was collaborated with research groups in environmental samples.

\section{References}

[1] Dao, C.A., Con, P.M. and Khai, N.M. (2010) Characteristic of Urban Wastewater in Hanoi City-Nutritive Value and 
Potential Risk in Using for agriculture. VNU Journal of Science, Earth Sciences, 26, 42-47.

[2] Cồn, P.M., Khải, N.M., Hà, P.Q. and Anh, T.N. (2013) Research on Surface Water Quality in Urban Area of Hanoi City. VNU Journal of Science, 24-30.

[3] Fetter, C.W. (1993) Applied Hydrogeology. Prentice Hall, Upper Saddle River.

[4] Katz, B.G., Coplen, T.B. and Bullen, T.D. (1997) Use of Chemical and Isotopic Tracers to Characterize the Interactions between Ground Water and Surface Water in Mantled Karst. Groundwater, 35, 1014-1028. http://dx.doi.org/10.1111/j.1745-6584.1997.tb00174.x

[5] Liu, X.C., Xia, J., Song, X.F., Yu, J.J., Tang, C.Y. and Zhan, C.S. (2005) Study of Surface Water and Groundwater Using Isotopes in Huaishahe Basin in Beijing, China. Proceedings of Symposium S3 Held during the Seventh IAHS Scientific Assembly, Foz do Iguaçu, Brazil, April.

\section{Submit or recommend next manuscript to SCIRP and we will provide best service for you:}

Accepting pre-submission inquiries through Email, Facebook, Linkedin, Twitter, etc A wide selection of journals (inclusive of 9 subjects, more than 200 journals)

Providing a 24-hour high-quality service

User-friendly online submission system

Fair and swift peer-review system

Efficient typesetting and proofreading procedure

Display of the result of downloads and visits, as well as the number of cited articles

Maximum dissemination of your research work

Submit your manuscript at: http://papersubmission.scirp.org/ 